Article

\title{
Design, Synthesis, and In Vitro Biological Activities of a Bio-Oxidizable Prodrug to Deliver Both ChEs and DYRK1A Inhibitors for AD Therapy
}

\author{
Anaïs Barré ${ }^{1,2}$, Rabah Azzouz ${ }^{1}$, Vincent Gembus ${ }^{1, * \mathbb{C}}$, Cyril Papamicaël ${ }^{2}$ and \\ Vincent Levacher $2, *$ (D) \\ 1 VFP Therapies R\&D; 1 rue Tesnière, 76130 Mont Saint-Aignan, France; anais.barre@insa-rouen.fr (A.B.); \\ razzouz@vfp-therapies.com (R.A.) \\ 2 Normandie University, UNIROUEN, INSA Rouen, CNRS, COBRA, 76000 Rouen, France; \\ cyril.papamicael@insa-rouen.fr \\ * Correspondence: vgembus@vfp-therapies.com (V.G.); vincent.levacher@insa-rouen.fr (V.L.); \\ Tel.: +33-023-554-2465 (V.G.)
}

Academic Editor: Ludovic Jean Received: 4 March 2019; Accepted: 28 March 2019; Published: 1 April 2019

\begin{abstract}
Despite their side effects, cholinesterase (ChE) inhibitors remain the only approved drugs to treat Alzheimer's disease patients, along with the $N$-methyl-D-aspartate (NMDA) receptor antagonist memantine. In the last few years, the dual-specificity tyrosine phosphorylation-regulated kinase $1 \mathrm{~A}$ (DYRK1A) has also been studied as a promising target for the development of new drugs for this pathology. In this context, and based on our previous characterization of bio-oxidizable prodrugs of potent acetylcholinesterase (AChE) inhibitors, we envisioned a strategy involving the synthesis of a bio-oxidizable prodrug of both ChE and DYRK1A inhibitors. To this end, we fixed our interest on a known potent inhibitor of DYRK1A, namely INDY. The designed prodrug of both ChE and DYRK1A inhibitors was successfully synthesized, connecting both inhibitors by a carbonate link. This prodrug and its corresponding drug were then evaluated as ChEs and DYRK1A inhibitors. Remarkably, in vitro results were in accordance with the starting hypothesis, showing a relative inactivity of the prodrug against DYRK1A and ChEs and a potent inhibition of ChEs by the oxidized form. Molecular docking and kinetic studies of $\mathrm{ChE}$ inhibition by the active compound are also discussed in this report.
\end{abstract}

Keywords: Alzheimer's; acetylcholinesterase; butyrylcholinesterase; DYRK1A kinase; prodrug; INDY

\section{Introduction}

To date, Alzheimer's disease (AD) represents 60 to 70 percent of dementia cases in the elderly, with a total 50 million cases in the world according World Health Organization data [1]. This mortal disease is still incurable, and the approved cholinesterase inhibitors (ChEIs) prescribed in the first stages of the disease, along with the $N$-methyl-D-aspartate (NMDA) receptor antagonist memantine, remain the only therapeutic tools for doctors to slow down the progression of memory and cognitive function impairments [2]. This is supported by the results of the many unsuccessfully clinical trials for other therapeutic approaches conducted in recent years [3,4]. Due to the multi-factorial aspect of $\mathrm{AD}$ and the observed synergic effects in several in vivo studies when two drugs are combined, researchers have turned their attention to this challenge and have developed hybrid compounds called multi-targeted directed ligands (MTDLs) [5-9]. Therefore, during the last decade, many active compounds based on the chemical structures of known AChEIs, and acting as AChEIs but also as inhibitors or ligands of other targets like BACE [10-12], monoamine oxidase [13,14], serotoninergic 
receptors [15-17], GS3K kinase [18,19], or others [20-25] have been described. Among other biological targets of interest for $\mathrm{AD}$, the dual-specificity tyrosine phosphorylation-regulated kinase 1A (DYRK1A) is also considered to be very promising [26-31]. Overexpressed in postmortem human AD brain [32], this kinase is thought to be responsible for hyperphosphorylation of the Tau protein, leading to a decrease in its affinity for microtubules that causes a disorganization of the cytoskeleton responsible for neuronal apoptosis [33]. Other reports also suggest a role of the DYRK1A activity in the amyloid beta peptide $(\mathrm{A} \beta)$ accumulation [34,35]. For many years, our group has been interested in the development of new ChEIs, with the aim of replacing the marketed AChEIs by more specific and less toxic ones [36-42]. In this context, we previously patented and reported on the design of brain-penetrant bio-oxidative prodrugs of potent pseudo-irreversible AChE carbamate-based inhibitors (Scheme 1A) [41]. Interestingly, we showed that modulation at the C-3 position was feasible without detriment for the inhibitory activity against $\mathrm{AChE}$, which thus constitutes a possible anchoring point for the design of new MTDL compounds. In particular, the highly potent compound $2 \mathrm{a}\left(\mathrm{IC}_{50}\right.$ value of $24 \mathrm{nM}$ ), with an amino-PEG chain, was selected to address this issue. A survey of the literature also showed us that a potent and selective inhibitor of DYRK1A, namely INDY 3 [43], was easily accessible, and comprised a phenol function that could serve as an anchor to be attached to our AChEI (Scheme 1B). Furthermore, masking the phenol function could prevent any inhibitory activity against the kinase [43]. With these thoughts in mind, we envisioned the synthesis of compound 4, designed to act as a dual prodrug of both AChE and DYRK1A inhibitors (Scheme 1C). The dihydroquinoline 4 should indeed be able to reach the brain to generate, after bio-oxidation, the corresponding quinonilium salt. The latter should exhibit an inhibitory effect not only against AChE, but also against DYRK1A, owing to the release of INDY 3 consecutively to the carbonate link hydrolysis. Here, we report the synthesis of compound 4 and the in vitro activity studies against ChEs and DYRK1A, as well as the molecular docking on ChEs.

A)<smiles>CN(C)C(=O)Oc1cc(C(C)(C)C)cc2c1cc(C(C)(C)C)c[n+]2C</smiles>

2a, $E W G=\mathrm{C}(\mathrm{O}) \mathrm{NH}\left(\mathrm{CH}_{2}\right)_{2} \mathrm{OH}, \mathrm{IC}_{50} h \mathrm{AChE}=24 \mathrm{nM}$
B)

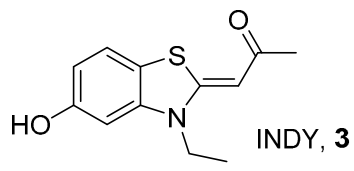

$\mathrm{IC}_{50} h \mathrm{DYRK} 1 \mathrm{~A}=240 \mathrm{nM}$

C)

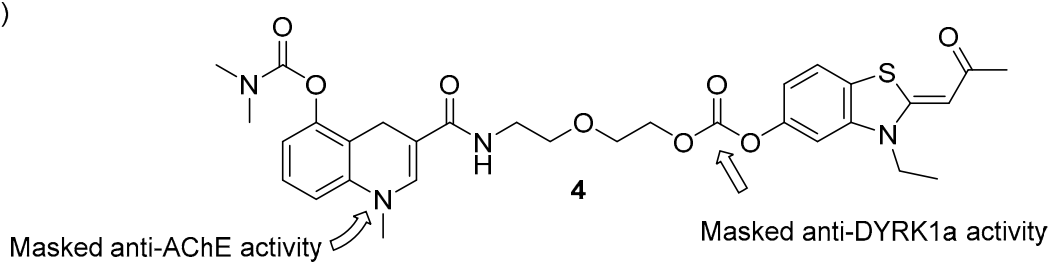

Scheme 1. (A) Previous set of prodrugs 1 of potent AChE inhibitors 2 [41]. (B) Structure of the known DYRK1A inhibitor INDY 3 [43]. (C) This work: prodrug design to deliver AChE/DYRK1A inhibitors into the brain.

\section{Results and Discussion}

\subsection{Chemistry}

Starting from the commercially available Boc-protected amino-alcohol 5 (Scheme 2), the mixed succinimidyl carbonate 6 was obtained quantitatively by reaction with disuccinimidyl carbonate (DSC) in the presence of triethylamine at room temperature. This linker derivative 6 was then reacted with the sodium phenoxide of INDY 3 , initially formed by deprotonation of INDY 3 in presence of 
sodium hydride, to to furnish compound 7 in good yield (75\%). Regarding the gram-scale synthesis of INDY 3, it was prepared in three steps from the available benzothiazole 9 with a good overall yield $(77 \%)$, and with only some minor experimental improvements of the procedure described by Hagiwara in 2004 [44]. Subsequently, the Boc group was classically removed in presence of an excess of trifluoroacetic acid (TFA) in dichloromethane at room temperature, leading to the expected ammonium salt 8 composed of the INDY moiety linked by a carbonate function to an amino-PEG chain.

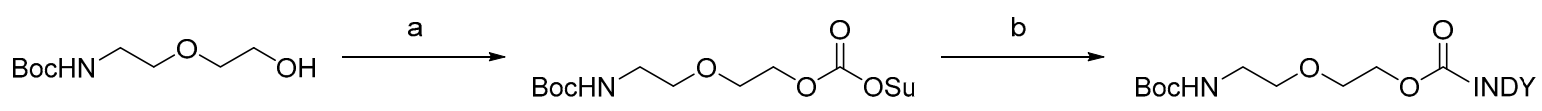

5

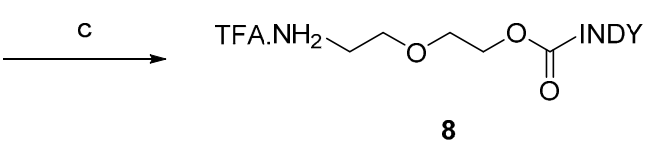

6

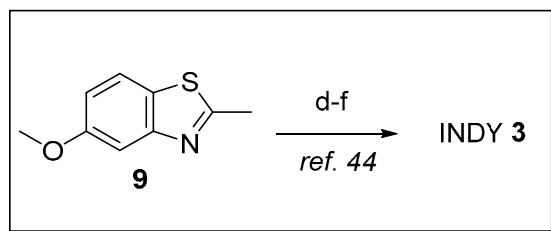

Scheme 2. Preparation of INDY 3 and fragment 8. Reagents and conditions: (a) DSC (2.0 equiv), $\mathrm{NEt}_{3}$ (2.0 equiv), ACN, rt, $2 \mathrm{~h}$ (quant.); (b) 3 (1.0 equiv), $\mathrm{NaH}$ (1.1 equiv) then, 6 (1.1 equiv), DMF, rt, $0.5 \mathrm{~h}$ (75\%); (c) TFA excess, DCM, rt, $0.5 \mathrm{~h}$ (quant.); (d) Ethyl iodide ( 15 equiv), sealed tube, $80{ }^{\circ} \mathrm{C}, 5$ days (96\%); (e) $\mathrm{Ac}_{2} \mathrm{O}$ (2.3 equiv), $\mathrm{NEt}_{3}$ (2.4 equiv), $\mathrm{ACN}$, reflux, $3 \mathrm{~h}(84 \%) ;(\mathbf{f}) \mathrm{BBr}_{3}$ (2.0 equiv), $\mathrm{DCM}, 0{ }^{\circ} \mathrm{C}$ to rt, $24 \mathrm{~h}(95 \%)$.

Next, compound $\mathbf{8}$ was reacted with the activated succinimidyl ester $\mathbf{1 0}$ prepared according to our previously described synthesis [45], to afford product 12 at a 71\% yield (Scheme 3). Under the same reaction conditions, with the succinimidyl ester $\mathbf{1 1}$ as reactant, compound $\mathbf{1 3}$ was also prepared, in order to demonstrate the influence of the carbamate at the C-5 position on the AChE inhibitory activity. The quinoline nitrogen of both compounds $\mathbf{1 2}$ and $\mathbf{1 3}$ was then selectively alkylated by action of dimethylsulfate to afford the corresponding quinolinium compounds 14 and 15 in excellent yields, $93 \%$ and $86 \%$, respectively. As a last step to access the prodrugs, the selective 1,4-reduction of compounds 14 and 15 was performed with benzyl-1,4-dihydronicotinamide (BNAH) at room temperature in dichloromethane to afford the dihydroquinolines 4 and $\mathbf{1 6}$ in good yields.<smiles>[R]c1cccc2ncc(C(=O)O[GaH])cc12</smiles>

10, $\mathrm{R}=\mathrm{OC}(\mathrm{O}) \mathrm{N}\left(\mathrm{CH}_{3}\right)_{2}$ 11, $\mathrm{R}=\mathrm{H}$

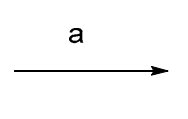<smiles>[Y9]NC(=O)OCCOCCNC(=O)c1cnc2cccc([R])c2c1</smiles><smiles>[R]c1cccc2c1cc(C(=O)NCCOCCOC(=O)[NH2+][Y9]([Y6])([H])[H])c[n+]2C</smiles><smiles>[R6]NC(=O)OCCOCCNC(=O)C1=CN(C)c2cccc([R])c2C1</smiles>

Scheme 3. Grafting of fragment 8 to quinoline moieties. Reagents and conditions: (a) 8 (1.0 equiv), $\mathrm{NEt}_{3}$ (5.0 equiv), $\mathrm{ACN}, 0{ }^{\circ} \mathrm{C}$ to rt, $0.5 \mathrm{~h}$ (12: 71\%, 13: 98\%); (b) $\mathrm{Me}_{2} \mathrm{SO}_{4}$ (1.1 equiv), DCE, sealed tube, $50{ }^{\circ} \mathrm{C}$, 24 h (14: 93\%, 15: 86\%); (c) BNAH (1.0 equiv), DCM, rt, 0.5 h (4: 72\%, 16: 80\%). 


\subsection{In Vitro Activity Evaluation}

Disposing of all envisioned products, the in vitro inhibitory activities on ChEs and DYRK1A were studied (Table 1). As expected, the bioprecursor 4 had only a modest effect on the inhibition of ChEs, with micromolar $\mathrm{IC}_{50}$ values. On the contrary, the oxidized form 14 displayed an excellent inhibition against $h \mathrm{AChE}$, with a two-digit nanomolar $\mathrm{IC}_{50}$ value. Interestingly, the compound $\mathbf{1 4}$ also exhibited a good inhibitory activity against butyrylcholinesterase (BuChE), which could be an asset because this enzyme is also able to hydrolyze acetylcholine and, in contrast to AChE, it is not degraded during the progression of the AD [46,47]. Moreover, a better propidium iodide displacement inhibition was observed with compound $\mathbf{1 4}$ compared to donepezil, whereas the corresponding prodrug 4 did not seem to interact with the peripheral anionic site [48] (PAS), as indicated by a poor inhibition of $4 \%$ under the same conditions. It is worth noting that quinolinium salt 15, lacking the carbamate moiety, did not show any significant inhibitory activity against either $\mathrm{ChE}$, thus underlining the importance of this transferable group in the mechanism of $\mathrm{ChE}$ inhibition by this class of compounds. The same remark is true for the corresponding dihydroquinoline 16. Unsurprisingly and as expected, none of the compounds showed any inhibitory activity against DYRK1A at one micromolar concentration compared to INDY.

Table 1. In vitro evaluation of compounds 4, 14-16.

\begin{tabular}{|c|c|c|c|c|}
\hline Compound & $\mathrm{IC}_{50} h \mathrm{AChE}(\mathrm{nM})^{1}$ & $\mathrm{IC}_{50} h \mathrm{BuChE}(\mathrm{nM})^{1}$ & $\begin{array}{c}\text { DYRK1a } \\
\text { Inhibition (\%) }\end{array}$ & $\begin{array}{l}\text { Propidium Iodide } \\
\text { Displacement } \\
\text { Inhibition }(\%)^{3}\end{array}$ \\
\hline $2 a^{2}$ & $37.1 \pm 0.1$ & $1440.2 \pm 286$ & 0 & - \\
\hline 14 & $81.4 \pm 0.4$ & $482 \pm 21$ & 5 & $26 \pm 1$ \\
\hline 15 & $>10,000$ & $6400 \pm 714$ & 6 & - \\
\hline 4 & $1023.1 \pm 72.1$ & $961 \pm 22$ & 8 & $4 \pm 2$ \\
\hline 16 & $>10,000$ & $>10,000$ & 7 & - \\
\hline Indy & $>10,000$ & $>10,000$ & 92 & - \\
\hline Donepezil & $15.3 \pm 1.7$ & - & - & $18 \pm 1$ \\
\hline Tacrine & - & $17.1 \pm 0.1$ & - & - \\
\hline
\end{tabular}

${ }^{1}$ Mean value of duplicate. ${ }^{2}$ Percentage of DYRK1A inhibition at $1 \mu \mathrm{M}\left(10 \mu \mathrm{M}\right.$ ATP concentration). ${ }^{3}$ Mean value of triplicate.

To support the assumption of the pseudo-irreversible inhibition mechanism of both ChEs by compound 14, kinetic studies were also performed using stopped time assays at different concentrations of ligand 14. Confirming the carbamate-mediated type inhibition, a progressive inhibition over time was observed with both enzymes (Figure 1). Using a nonlinear regression fitting analysis, the pseudo-first-order inhibition rate constant $\left(\mathrm{k}_{\mathrm{obs}}\right)$ for each concentration of $\mathbf{1 4}$ was obtained and the equilibrium constant $(\mathrm{Kc})$ and the carbamoylation rate constant $\left(\mathrm{k}_{3}\right)$ was determined by the reported method $[49,50]$. Compound 14 showed good affinities for $h \mathrm{AChE}$ and $h \mathrm{BChE}$, with Kc values of 229.8 and $659.1 \mathrm{nM}$ respectively, and good rates of carbamate transfer $\left(\mathrm{k}_{3}\right)$, with values of 0.408 and $0.574 \mathrm{~min}^{-1}$, respectively. Consequently, the second order rate constant $\mathrm{Ki}$, defined as $\mathrm{k}_{3} / \mathrm{Kc}$, and reflecting the carbamylation efficacy, was $1.78 \mu \mathrm{M}^{-1} \cdot \mathrm{min}^{-1}$ with $h \mathrm{AChE}$ and $0.87 \mu \mathrm{M}^{-1} \cdot \mathrm{min}^{-1}$ with $h \mathrm{BuChE}$. 
A)

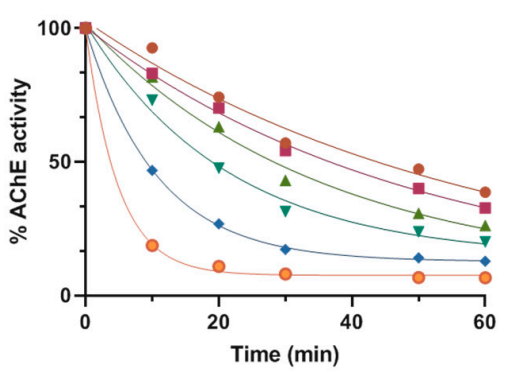

B)

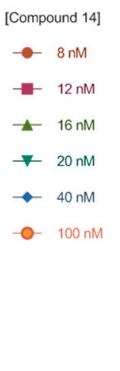

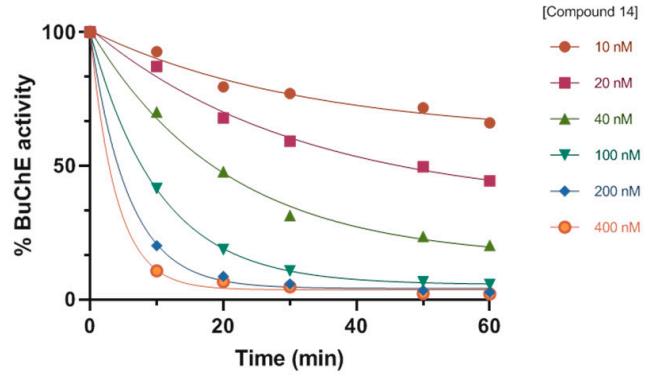

Figure 1. Plots of the decay curves for (A) rhAChE inhibition by compound 14 (8-100 nM) and (B) $h \mathrm{BuChE}$ inhibition by compound $14(10-400 \mathrm{nM})$. This figure was made with Prism 8.0 [51].

As a complement to the preceding studies, the ability of compounds 14 and 4 to cross the blood brain barrier (BBB) by passive diffusion was determined by PAMPA BBB assays. Unsurprisingly [39-42], the obtained values showed that the quinolinium salt $\mathbf{1 4}$ is not able to cross the BBB by this transport process $\left(\mathrm{Pe}=0.00 \times 10^{-6} \mathrm{~cm} \cdot \mathrm{s}^{-1}\right)$, whereas the dihydroquinoline compound 4, which is more lipophilic, diffuses moderately $\left(\mathrm{Pe}=2.41 \times 10^{-6} \mathrm{~cm} \cdot \mathrm{s}^{-1}\right)$.

\subsection{Docking}

In order to determine which favorable binding interactions can contribute to the potent inhibition of ChEs by compound 14, docking experiments were performed. In the best docking pose on $h \mathrm{AChE}$ (PDB: 4EY7, Figure 2A), the carbamate group of compound 14 is favorably oriented toward the Ser 203 residue $(1.96 \AA)$. Whereas the quinolinium moiety has $\pi-\pi$ interactions with $\operatorname{Trp} 86$, the positive nitrogen resulted in a favorable attractive interaction with the Asp 74 residue (4.94 $\AA$ ). Hydrogen bond interactions between the carbonyl of amide and Tyr 337 residue $(2.7 \AA)$, and between oxygen of the carbonate and Phe 295 residue $(2.1 \AA)$ also seem to be advantageous for the binding affinity. Supporting the potential interactions of compound 14 with the PAS, docking suggests that the benzothiazole moiety can be $\pi$-stacked with the Trp 286 residue $(4.64 \AA$ ) of the PAS, with a possible $\pi$-sulfur interaction between the thiazole moiety of the ligand and the same residue (4.16 $\AA$ ).
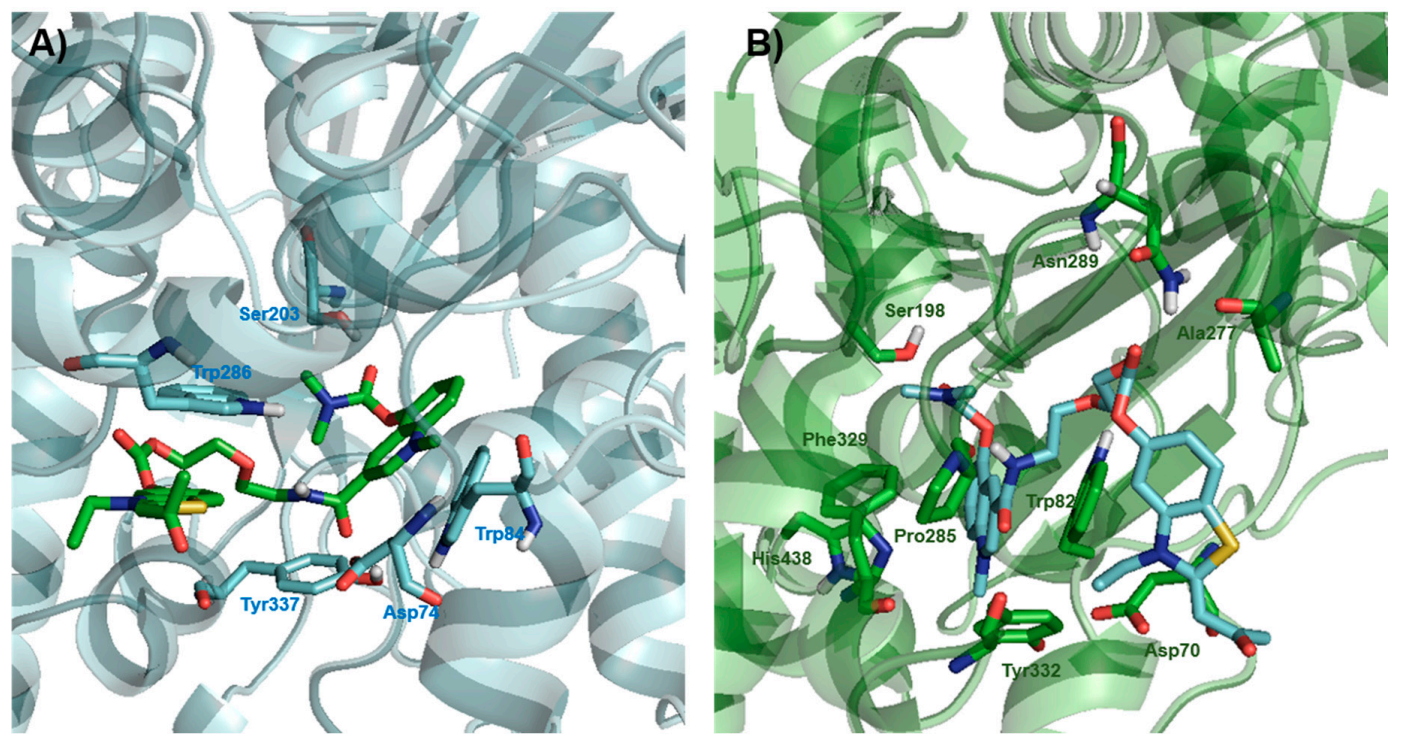

Figure 2. Top-scored pose obtained with Autodock Vina [52] for compound 14 positioned in (A) the active site of $r h \mathrm{AChE}$ (PDB ID: 4EY7), and (B) the active site of $h \mathrm{BuChE}$ (PDB ID: 1P0I). The compound and the selected side chains of the binding site residues are in stick and the protein in cartoon representation. This figure was made with PyMol [53]. 
In the top-scored pose in $h \mathrm{BuChE}$ (PDB: 1P0I, Figure 2B), ligand 14 is favorably positioned in the catalytic site to permit the transfer of the carbamate group to Ser 198 ( $2.9 \AA)$. The main interactions are illustrated by a $\pi-\pi$ stacking between the quinolinum moiety of ligand 14 with the Trp $82(4.1 \AA)$, and by T-shaped stacking with the His438 and Phe329 residues (resp., 4.9 and $5.4 \AA$ ). An additional attractive charge interaction $(4.7 \AA)$ between the positive nitrogen and the Asp 70 residue could improve the binding affinity of compound $\mathbf{1 4}$ for $h \mathrm{BuChE}$. Additionally, hydrogen bond interactions between the NH group of the amide function and the Pro285 residue $(2.1 \AA)$, as well as between the carbonyl of the carbonate group and the Asn 289 residue (2.2 $\AA$ ), can also contribute to favorable binding interactions. According to this pose, the benzothiazole part of compound 14 would interact with Tyr 332 residue through a $\pi-\pi$ interaction (T-stacking, $5.2 \AA$ ), and with Ala 277 through a $\pi-$ alkyl interaction (5.1 $\AA$ ).

\section{Conclusions}

In conclusion, the envisioned compound $\mathbf{4}$ and its corresponding quinolinium salt $\mathbf{1 4}$ were successfully prepared in six steps, starting from the previously described succinimidyl ester $\mathbf{1 0}$ and the Boc-protected amino-alcohol 5. As expected, the quinolinium compound $\mathbf{1 4}$ showed a potent inhibitory activity against both the CAS and the PAS of $h \mathrm{AChE}$ and also, more pleasingly, against $h \mathrm{BuChE}$. Put together, in vitro assay findings suggested that the observed dual inhibition of both AChE and BuChE by compound 14 could be explained by a pseudo-irreversible mechanism. This was also corroborated by the docking studies of $\mathbf{1 4}$ on both enzymes. Equally importantly, and as expected, we also showed that the carbonate link installed between INDY $\mathbf{3}$ and $\mathbf{2 a}$ allowed transient masking of the inhibitory activity of INDY 3 against DYRK1A. Overall, these in vitro activity data are very encouraging for the future development of compound 4 as prodrug of selective central ChE and DYRK1A inhibitors. Further in vivo studies on small animals will be required to evaluate the potential of this prodrug approach and, in particular, to validate the release of INDY 3 into the brain.

\section{Experimental Section}

\subsection{General Information}

All purchased reagents were used as received. The solvents were used anhydrous directly from suppliers, or by drying with appropriate desiccants followed by distillation. Flash column chromatography was performed on silica gel (70-230 mesh), and thin layer chromatography used to monitor the reactions was carried out using commercial silica gel plates. NMR spectra $\left({ }^{1} \mathrm{H}\right.$ and $\left.{ }^{13} \mathrm{C}\right)$ were recorded using a Bruker Avance $300 \mathrm{MHz}$ spectrometer ((Bruker, Wissembourg, France). Unless otherwise specified, DMSO- $d_{6}$ or $\mathrm{CDCl}_{3}$ served as internal standard (see Supplementary Materials). Peak multiplicities are reported as follow: $\mathrm{s}=$ singlet, $\mathrm{d}=$ doublet, $\mathrm{t}=$ triplet, $\mathrm{q}=$ quadruplet, $\mathrm{dd}=$ doublet of doublet, $\mathrm{br}=$ broad, apt $=$ apparent triplet, and $\mathrm{m}=$ multiplet, coupling constants $(J$ in $\mathrm{Hz}$ ) and chemical shifts are given in ppm. High-resolution mass spectrometry (HRMS) was carried out on a Waters LCT XE spectrometer (WATERS, Guyancourt, France). Compounds 10 and 3 were synthesized using a previously described synthesis [44,45].

\subsection{Chemistry}

tert-Butyl (2-(2-(((2,5-dioxopyrrolidin-1-yl)oxy)carbonyl)oxy)ethoxy)ethyl)carbamate (6): Commercial tert-butyl N-[2-(2-hydroxyethoxy)ethyl]carbamate $5(146 \mu \mathrm{L}, 1.03 \mathrm{mmol}, 1.0$ equiv) was dissolved in dry acetonitrile $(10 \mathrm{~mL})$. Triethylamine $\left(288 \mu \mathrm{L}, 2.07 \mathrm{mmol}, 2.0\right.$ equiv) and $N, N^{\prime}$-disuccinimidyl carbonate (530 mg, $2.07 \mathrm{mmol}, 2.0$ equiv) were added, and the mixture was stirred for $2 \mathrm{~h}$ at room temperature. The solvent was removed in vacuo, and the residue was taken up in a saturated aqueous solution of sodium bicarbonate. The product was extracted three times with dichloromethane, dried over $\mathrm{MgSO}_{4}$, and concentrated to dryness. The crude product was purified by column chromatography $\left(\mathrm{SiO}_{2}\right.$, $\mathrm{EtOAc} / \mathrm{PE}=1: 2, R_{f}=0.37[\mathrm{EtOAc} / \mathrm{PE}=1: 1]$ ) to give the expected compound 6 (358 $\mathrm{mg}$, quantitative 
yield) as a colorless oil. IR $v_{\max } / \mathrm{cm}^{-1} 3387,2977,1737,1702,1220,1201 .{ }^{1} \mathrm{H}-\mathrm{NMR}\left(300 \mathrm{MHz}, \mathrm{CDCl}_{3}\right)$ $\delta 5.01(\mathrm{br} \mathrm{s}, 1 \mathrm{H}, \mathrm{NH}), 4.50-4.43(\mathrm{~m}, 2 \mathrm{H}), 3.76-3.71(\mathrm{~m}, 2 \mathrm{H}), 3.55(\mathrm{t}, J=5.1 \mathrm{~Hz}, 2 \mathrm{H}), 3.32(\mathrm{q}, J=5.2 \mathrm{~Hz}$, 2H), $2.85(\mathrm{~s}, 4 \mathrm{H}), 1.45(\mathrm{~s}, 9 \mathrm{H}) ;{ }^{13} \mathrm{C}-\mathrm{NMR}\left(75 \mathrm{MHz}, \mathrm{CDCl}_{3}\right) \delta 168.8,155.9,151.5,78.9,70.2,69.8,67.8,40.1$, 28.2, 25.3; HRMS (TOF-ESI ${ }^{+}$) calcd. for $[\mathrm{M}+\mathrm{H}]^{+} \mathrm{C}_{14} \mathrm{H}_{23} \mathrm{~N}_{2} \mathrm{O}_{8} \mathrm{~m} / z$ 347.1449, found 347.1459.

(Z)-tert-Butyl(2-(2-((((3-ethyl-2-(2-oxopropylidene)-2,3-dihydrobenzo[d]thiazol-5-yl)oxy)carbonyl)oxy)ethoxy) ethyl)carbamate (7): INDY 3 ( $46 \mathrm{mg}, 0.20 \mathrm{mmol}, 1.0$ equiv) and sodium hydride ( $60 \%$ dispersion in oil, $9 \mathrm{mg}, 0.22 \mathrm{mmol}, 1.1$ equiv) were dissolved in dry dimethylformamide (4 mL). After $5 \mathrm{~min}$, the succinymidyl carbonate 6 ( $74 \mathrm{mg}, 0.22 \mathrm{mmol}, 1.1$ equiv) was added. After $20 \mathrm{~min}$ the reaction mixture was quenched with water at $0{ }^{\circ} \mathrm{C}$, extracted with dichloromethane, washed with brine, dried over $\mathrm{MgSO}_{4}$, and evaporated to dryness. The crude product was purified by column chromatography $\left(\mathrm{SiO}_{2}, \mathrm{EtOAc} / \mathrm{PE}=1: 2\right.$ to 1:1, $R_{f}=0.65$ [EtOAc 100\%]) to afford the expected compound $7(68 \mathrm{mg}$, $75 \%$ ) as a white hygroscopic solid. IR $v_{\max } / \mathrm{cm}^{-1} 2977,1763,1706,1493,1471,1247,1193 .{ }^{1} \mathrm{H}-\mathrm{NMR}$ $\left(300 \mathrm{MHz}, \mathrm{CDCl}_{3}\right) \delta 7.47(\mathrm{~d}, J=8.4 \mathrm{~Hz}, 1 \mathrm{H}), 6.95-6.92(\mathrm{~m}, 2 \mathrm{H}), 5.85(\mathrm{~s}, 1 \mathrm{H}), 5.00(\mathrm{~s}, 1 \mathrm{H}, \mathrm{NH}), 4.38-4.35$ $(\mathrm{m}, 2 \mathrm{H}), 3.97(\mathrm{q}, J=7.2 \mathrm{~Hz}, 2 \mathrm{H}), 3.74-3.68(\mathrm{~m}, 2 \mathrm{H}), 3.56-3.53(\mathrm{~m}, 2 \mathrm{H}), 3.33-3.28(\mathrm{~m}, 2 \mathrm{H}), 2.19(\mathrm{~s}, 3 \mathrm{H})$, $1.39(\mathrm{~s}, 9 \mathrm{H}), 1.31(\mathrm{t}, J=7.2 \mathrm{~Hz}, 3 \mathrm{H}) ;{ }^{13} \mathrm{C}-\mathrm{NMR}\left(75 \mathrm{MHz}, \mathrm{CDCl}_{3}\right) \delta 191.5,160.4,156.0,153.6,150.2,140.0$, $124.8,122.7,115.5,103.0,90.5,79.3,70.3,68.4,67.8,40.8,40.3,29.0,28.4,11.5$; HRMS (TOF-ESI ${ }^{+}$) calcd. for $[\mathrm{M}+\mathrm{H}]^{+} \mathrm{C}_{22} \mathrm{H}_{31} \mathrm{~N}_{2} \mathrm{O}_{7} \mathrm{~S} \mathrm{~m} / z$ 467.1846, found 467.1850.

(Z)-2-(2-(((3-Ethyl-2-(2-oxopropylidene)-2,3-dihydrobenzo[d]thiazol-5-yl)oxy)carbonyl)oxy)ethoxy)ethanaminium 2,2,2-trifluoroacetate (8): Compound $7(132 \mathrm{mg}, 0.28 \mathrm{mmol}, 1.0$ equiv) was dissolved in dry dichloromethane $(3 \mathrm{~mL})$. Trifluoroacetic acid $(0.65 \mathrm{~mL}, 8.49 \mathrm{mmol}, 30$ equiv) was added, and after $20 \mathrm{~min}$ the reaction mixture was evaporated to dryness to afford the expected compound 8 (quantitative yield) as a light brown oil. IR $v_{\max } / \mathrm{cm}^{-1} 2925,1764,1673,1180,1131,974,798,705$. ${ }^{1} \mathrm{H}-\mathrm{NMR}\left(300 \mathrm{MHz}, \mathrm{DMSO}-d_{6}\right) \delta 7.80(\mathrm{~m}, 4 \mathrm{H}), 7.41(\mathrm{br} \mathrm{s}, 1 \mathrm{H}), 7.05(\mathrm{~d}, J=8.4 \mathrm{~Hz}, 1 \mathrm{H}), 6.15(\mathrm{~s}, 1 \mathrm{H})$, 4.41-4.35 (m, 2H), 4.17-4.09 (m, 2H), 3.79-3.73 (m, 2H), $3.65(\mathrm{t}, J=5.2 \mathrm{~Hz}, 2 \mathrm{H}), 3.06-2.97(\mathrm{~m}, 2 \mathrm{H}), 2.12$ $(\mathrm{s}, 3 \mathrm{H}), 1.22(\mathrm{t}, J=7.0 \mathrm{~Hz}, 3 \mathrm{H}) ;{ }^{13} \mathrm{C}-\mathrm{NMR}\left(75 \mathrm{MHz}, \mathrm{DMSO}-d_{6}\right) \delta 190.2,159.3,153.3,150.2,140.1,123.8$, 123.1, 118.0, 115.8, 114.1, 104.3, 90.7, 68.1, 67.8, 66.8, 40.5, 38.6, 28.7, 11.5; HRMS (TOF-ESI ${ }^{+}$) calcd. for $\left[\mathrm{M}-\mathrm{CF}_{3} \mathrm{COO}^{-}\right]^{+} \mathrm{C}_{17} \mathrm{H}_{23} \mathrm{~N}_{2} \mathrm{O}_{5} \mathrm{~S}$ m/z 367.1322, found 367.1331.

General procedure for synthesis of compounds 12 and 13: Compound 8 (1.0 equiv) was dissolved in dry acetonitrile $(0.1 \mathrm{M})$. The solution was cooled to $0{ }^{\circ} \mathrm{C}$ and triethylamine (5.0 equiv) was added. A solution of quinoline 10 (1.0 equiv) in dry acetonitrile $(5 \mathrm{~mL} / \mathrm{mmol})$ was then added at room temperature. After $30 \mathrm{~min}$, the reaction mixture was evaporated to dryness, the residue was taken up in water, extracted four times with dichloromethane, washed with brine, dried over $\mathrm{MgSO}_{4}$, and concentrated in vacuo. The crude product was purified by column chromatography on silica gel.

(Z)-3-((2-(2-((((3-Ethyl-2-(2-oxopropylidene)-2,3-dihydrobenzo[d]thiazol-5-yl)oxy)carbonyl)oxy)ethoxy)ethyl) carbamoyl)quinolin-5-yl dimethylcarbamate (12): Starting from compound 10 (174 mg, $0.487 \mathrm{mmol})$, compound 12 was obtained as a beige solid ( $214 \mathrm{mg}, 71 \%)$ after purification by column chromatography $\left(\mathrm{SiO}_{2}, \mathrm{EtOAc} 100 \%\right.$ to ACN $/ \mathrm{EtOAc}=4: 1, R_{f}=0.18$ [ACN $/$ EtOAc $\left.\left.=1: 3\right]\right) . \mathrm{Mp} 102-104{ }^{\circ} \mathrm{C}$. IR $v_{\max } / \mathrm{cm}^{-1} 2940,1723,1468,1232,1192,969 .{ }^{1} \mathrm{H}-\mathrm{NMR}\left(300 \mathrm{MHz}, \mathrm{CDCl}_{3}\right) \delta 9.21(\mathrm{~d}, J=2.1 \mathrm{~Hz}, 1 \mathrm{H})$, $8.75(\mathrm{~d}, J=2.0 \mathrm{~Hz}, 1 \mathrm{H}), 7.91(\mathrm{~d}, J=8.5 \mathrm{~Hz}, 1 \mathrm{H}), 7.72(\mathrm{appt}, J=8.1 \mathrm{~Hz}, 1 \mathrm{H}), 7.41(\mathrm{~d}, J=8.4 \mathrm{~Hz}, 1 \mathrm{H}), 7.36$ $(\mathrm{d}, J=7.6 \mathrm{~Hz}, 1 \mathrm{H}), 7.02(\mathrm{br} \mathrm{s}, 1 \mathrm{H}, \mathrm{NH}), 6.89(\mathrm{dd}, J=8.4,2.0 \mathrm{~Hz}, 1 \mathrm{H}), 6.85(\mathrm{~d}, J=1.9 \mathrm{~Hz}, 1 \mathrm{H}), 5.84(\mathrm{~s}, 1 \mathrm{H})$, $4.48-4.41(\mathrm{~m}, 2 \mathrm{H}), 3.90(\mathrm{q}, J=7.3 \mathrm{~Hz}, 2 \mathrm{H}), 3.85-3.80(\mathrm{~m}, 2 \mathrm{H}), 3.77(\mathrm{br} \mathrm{s}, 4 \mathrm{H}), 3.25(\mathrm{~s}, 3 \mathrm{H}), 3.05(\mathrm{~s}, 3 \mathrm{H})$, $2.23(\mathrm{~s}, 3 \mathrm{H}), 1.28(\mathrm{t}, J=7.2 \mathrm{~Hz}, 3 \mathrm{H}) ;{ }^{13} \mathrm{C}-\mathrm{NMR}\left(75 \mathrm{MHz}, \mathrm{CDCl}_{3}\right) \delta 191.6,165.8,160.5,154.5,153.9,150.1$, $149.7,148.2,147.6,140.0,130.8,130.6,127.0,126.6,125.0,122.8,121.8,119.7,115.4,102.9,90.6,69.7,68.9$, 67.7, 40.8, 40.1, 37.1, 36.9, 29.2, 11.6; HRMS (TOF-ESI ${ }^{+}$) calcd. for $[\mathrm{M}+\mathrm{H}]^{+} \mathrm{C}_{30} \mathrm{H}_{33} \mathrm{~N}_{4} \mathrm{O}_{8} \mathrm{~S}$ m/z 609.2014, found 609.2004 .

(Z)-3-Ethyl-2-(2-oxopropylidene)-2,3-dihydrobenzo[d]thiazol-5-yl (2-(2-(quinoline-3-carboxamido)ethoxy)ethyl) carbonate (13): Starting from compound 10 (143 mg, $0.53 \mathrm{mmol})$, compound 13 was obtained as a white, very hygroscopic solid ( $270 \mathrm{mg}$, 98\%) after purification by column chromatography $\left(\mathrm{SiO}_{2}\right.$, 
$\mathrm{EtOAc} / \mathrm{PE}=1: 1$ to EtOAc 100\%, $R_{f}=0.17$ [EtOAc 100\%]). IR $v_{\max } / \mathrm{cm}^{-1} 3237,1753,1649,1246,1067$. ${ }^{1} \mathrm{H}-\mathrm{NMR}\left(300 \mathrm{MHz}, \mathrm{CDCl}_{3}\right) \delta 9.28(\mathrm{~d}, J=2.1 \mathrm{~Hz}, 1 \mathrm{H}), 8.56(\mathrm{~d}, J=1.7 \mathrm{~Hz}, 1 \mathrm{H}), 8.01(\mathrm{~d}, J=8.5 \mathrm{~Hz}, 1 \mathrm{H})$, 7.73-7.63 (m, 2H), $7.44(\mathrm{t}, J=7.5 \mathrm{~Hz}, 1 \mathrm{H}), 7.37(\mathrm{br} \mathrm{s}, 1 \mathrm{H}, \mathrm{NH}), 7.34(\mathrm{~d}, J=8.4 \mathrm{~Hz}, 1 \mathrm{H}), 6.85(\mathrm{dd}, J=8.4$, $1.9 \mathrm{~Hz}, 1 \mathrm{H}), 6.80(\mathrm{~d}, J=1.7 \mathrm{~Hz}, 1 \mathrm{H}), 5.79(\mathrm{~s}, 1 \mathrm{H}), 4.48-4.38(\mathrm{~m}, 2 \mathrm{H}), 3.88-3.48(\mathrm{~m}, 8 \mathrm{H}), 2.20(\mathrm{~s}, 3 \mathrm{H})$, $1.22(\mathrm{t}, J=7.1 \mathrm{~Hz}, 3 \mathrm{H}) ;{ }^{13} \mathrm{C}-\mathrm{NMR}\left(75 \mathrm{MHz}, \mathrm{CDCl}_{3}\right) \delta 191.6,165.9,160.4,153.8,150.0,149.0,148.5,139.9$, 135.7, 131.2, 129.1, 128.7, 127.3, 126.8, 126.8, 124.8, 122.7, 115.4, 102.9, 90.5, 69.7, 68.7, 67.7, 40.7, 39.9, 29.1, 11.5; HRMS (TOF-ESI ${ }^{+}$) calcd. for $[\mathrm{M}+\mathrm{H}]^{+} \mathrm{C}_{27} \mathrm{H}_{28} \mathrm{~N}_{3} \mathrm{O}_{6} \mathrm{~S} \mathrm{~m} / z$ 522.1693, found 522.1710.

General procedure for synthesis of compounds 14 and 15: Quinoline compound (1.0 equiv) was dissolved in dry dichloroethane $(5 \mathrm{~mL} / \mathrm{mmol})$ in a sealed tube. Dimethyl sulfate (1.1 equiv) was then added, and the resulting solution was heated at $50{ }^{\circ} \mathrm{C}$. After completion of the reaction, diethyl ether was added at room temperature, and the solid was filtered and dried in vacuo to afford the expected quinolinium compound 14, which was used without further purification.

(Z)-5-((Dimethylcarbamoyl)oxy)-3-((2-(2-((((3-ethyl-2-(2-oxopropylidene)-2,3-dihydrobenzo[d]thiazol-5-yl)oxy) carbonyl)oxy)ethoxy)ethyl)carbamoyl)-1-methylquinolin-1-ium methyl sulfate (14): From quinoline 12 (133 mg, $0.219 \mathrm{mmol})$, compound 14 was isolated as a purple solid $(150 \mathrm{mg}, 93 \%)$. Mp 84-85 ${ }^{\circ} \mathrm{C}$. IR $v_{\max } / \mathrm{cm}^{-1} 3273,3087,2944,1732,1468,1193,1004,740 .{ }^{1} \mathrm{H}-\mathrm{NMR}\left(300 \mathrm{MHz}, \mathrm{DMSO}-d_{6}\right) \delta 9.92(\mathrm{~s}, 1 \mathrm{H})$, 9.55-9.42 (m, 2H), 8.45-8.28 (m, 2H), 7.97-7.87 (m, 1H), $7.67(\mathrm{~d}, J=8.4 \mathrm{~Hz}, 1 \mathrm{H}), 7.34(\mathrm{~d}, J=1.9 \mathrm{~Hz}, 1 \mathrm{H})$, $6.96(\mathrm{dd}, J=8.4,1.9 \mathrm{~Hz}, 1 \mathrm{H}), 6.13(\mathrm{~s}, 1 \mathrm{H}), 4.67(\mathrm{~s}, 3 \mathrm{H}), 4.42-4.30(\mathrm{~m}, 2 \mathrm{H}), 4.14-4.05(\mathrm{~m}, 2 \mathrm{H}), 3.82-3.73$ $(\mathrm{m}, 2 \mathrm{H}), 3.73-3.64(\mathrm{~m}, 2 \mathrm{H}), 3.64-3.54(\mathrm{~m}, 2 \mathrm{H}), 3.36(\mathrm{~s}, 3 \mathrm{H}), 3.26(\mathrm{~s}, 3 \mathrm{H}), 3.02(\mathrm{~s}, 3 \mathrm{H}), 2.12(\mathrm{~s}, 3 \mathrm{H}), 1.19$ $(\mathrm{t}, J=7.0 \mathrm{~Hz}, 3 \mathrm{H}) ;{ }^{13} \mathrm{C}-\mathrm{NMR}\left(75 \mathrm{MHz}, \mathrm{DMSO}-d_{6}\right) \delta 190.2,162.4,161.8,158.9,153.1,153.0,150.7,150.0$, 148.7, 139.9, 139.0, 138.5, 136.6, 127.5, 123.6, 123.0, 122.9, 116.2, 115.5, 104.0, 90.6, 68.6, 68.0, 67.8, 52.9, $46.1,44.1,40.3,39.7,36.8,36.6,28.8,11.4$; HRMS (TOF-ESI ${ }^{+}$) calcd. for $\left[\mathrm{M}-\mathrm{MeSO}_{4}{ }^{-}\right]^{+} \mathrm{C}_{31} \mathrm{H}_{35} \mathrm{~N}_{4} \mathrm{O}_{8} \mathrm{~S}$ $m / z$ 623.2170, found 623.2170.

(Z)-3-((2-(2-((((3-Ethyl-2-(2-oxopropylidene)-2,3-dihydrobenzo[d]thiazol-5-yl)oxy)carbonyl)oxy)ethoxy)ethyl) carbamoyl)-1-methylquinolin-1-ium methyl sulfate (15): From quinoline 13 (75 mg, $0.144 \mathrm{mmol}$ ), compound 15 was isolated as a pale pink solid ( $80 \mathrm{mg}, 86 \%$ ). Mp $183^{\circ} \mathrm{C}$ (decomp.). IR $v_{\max } / \mathrm{cm}^{-1}$ 3308, 3067, 1755, 1463, 1230, 974, 745. ${ }^{1} \mathrm{H}-\mathrm{NMR}(300 \mathrm{MHz}$, DMSO-d 6 ) $\delta 9.88(\mathrm{~s}, 1 \mathrm{H}), 9.63(\mathrm{~s}, 1 \mathrm{H}), 9.28$ (br t, $J=5.5 \mathrm{~Hz}, 1 \mathrm{H}), 8.52(\mathrm{~d}, J=8.9 \mathrm{~Hz}, 1 \mathrm{H}), 8.47(\mathrm{~d}, J=8.1 \mathrm{~Hz}, 1 \mathrm{H}), 8.37-8.28(\mathrm{~m}, 1 \mathrm{H}), 8.12-8.03$ $(\mathrm{m}, 1 \mathrm{H}), 7.70(\mathrm{~d}, J=8.4 \mathrm{~Hz}, 1 \mathrm{H}), 7.35(\mathrm{~d}, J=1.8 \mathrm{~Hz}, 1 \mathrm{H}), 6.98(\mathrm{dd}, J=8.4,2.0 \mathrm{~Hz}, 1 \mathrm{H}), 6.13(\mathrm{~s}, 1 \mathrm{H})$, $4.66(\mathrm{~s}, 3 \mathrm{H}), 4.41-4.34(\mathrm{~m}, 2 \mathrm{H}), 4.09(\mathrm{q}, J=7.1 \mathrm{~Hz}, 2 \mathrm{H}), 3.81-3.73(\mathrm{~m}, 2 \mathrm{H}), 3.73-3.65(\mathrm{~m}, 2 \mathrm{H}), 3.63-3.55$ $(\mathrm{m}, 2 \mathrm{H}), 3.36(\mathrm{~s}, 3 \mathrm{H}), 2.12(\mathrm{~s}, 3 \mathrm{H}), 1.19(\mathrm{t}, J=7.0 \mathrm{~Hz}, 3 \mathrm{H}) ;{ }^{13} \mathrm{C}-\mathrm{NMR}\left(75 \mathrm{MHz}\right.$, DMSO- $\left.d_{6}\right) \delta 190.1,161.9$, 158.9, 153.1, 150.0, 149.8, 144.9, 139.8, 138.7, 136.7, 131.3, 130.6, 128.1, 127.6, 123.6, 122.9, 119.3, 115.5, 104.0, 90.5, 68.6, 67.9, 67.8, 52.8, 45.6, 40.3, 39.6, 28.8, 11.4; HRMS (TOF-ESI ${ }^{+}$) calcd. for $\left[\mathrm{M}-\mathrm{MeSO}_{4}{ }^{-}\right]^{+}$ $\mathrm{C}_{28} \mathrm{H}_{30} \mathrm{~N}_{3} \mathrm{O}_{6} \mathrm{~S} m / z$ 539.1848, found 536.1850.

General procedure for synthesis of compounds 4 and 16: Quinolinium salt (1.1 equiv) and BNAH (1.0 equiv) were dissolved in degassed dichloromethane $(10 \mathrm{~mL} / \mathrm{mmol})$ in the dark, under argon atmosphere. After $30 \mathrm{~min}$ of stirring at room temperature in the dark, the solution was washed three times with degassed water, dried over $\mathrm{MgSO}_{4}$, and evaporated to dryness to give the expected dihydroquinoline, which was used without further purification.

(Z)-3-((2-(2-(((3-Ethyl-2-(2-oxopropylidene)-2,3-dihydrobenzo[d]thiazol-5-yl)oxy)carbonyl)oxy)ethoxy)ethyl) carbamoyl)-1-methyl-1,4-dihydroquinolin-5-yl dimethylcarbamate (4): From quinolinium salt 14 (113 mg, $0.154 \mathrm{mmol})$ and BNAH (30 mg, $140 \mathrm{mmol})$, the expected dihydroquinoline $4(63 \mathrm{mg}, 72 \%)$ was obtained as a pale orange solid. Mp 89-91 ${ }^{\circ} \mathrm{C}$. IR $v_{\max } / \mathrm{cm}^{-1} 2922,1717,1667,1469,1231 .{ }^{1} \mathrm{H}-\mathrm{NMR}$ $\left(300 \mathrm{MHz}, \mathrm{DMSO}-d_{6}\right) \delta 7.73(\mathrm{~d}, J=8.4 \mathrm{~Hz}, 1 \mathrm{H}), 7.46-7.39(\mathrm{~m}, 2 \mathrm{H}), 7.15-7.08(\mathrm{~m}, 2 \mathrm{H}), 7.05(\mathrm{dd}, J=8.4$, $1.9 \mathrm{~Hz}, 1 \mathrm{H}), 6.64(\mathrm{~d}, J=8.2 \mathrm{~Hz}, 2 \mathrm{H}), 6.14(\mathrm{~s}, 1 \mathrm{H}), 4.38-4.31(\mathrm{~m}, 2 \mathrm{H}), 4.12(\mathrm{q}, J=6.9 \mathrm{~Hz}, 2 \mathrm{H}), 3.73-3.67$ $(\mathrm{m}, 2 \mathrm{H}), 3.51(\mathrm{appt}, J=6.0 \mathrm{~Hz}, 2 \mathrm{H}), 3.44(\mathrm{~s}, 2 \mathrm{H}), 3.34-3.27(\mathrm{~m}, 2 \mathrm{H}), 3.14(\mathrm{~s}, 3 \mathrm{H}), 3.06(\mathrm{~s}, 3 \mathrm{H}), 2.91(\mathrm{~s}, 3 \mathrm{H})$, $2.12(\mathrm{~s}, 3 \mathrm{H}), 1.20(\mathrm{t}, J=7.1 \mathrm{~Hz}, 3 \mathrm{H}) ;{ }^{13} \mathrm{C}-\mathrm{NMR}\left(75 \mathrm{MHz}, \mathrm{DMSO}-d_{6}\right) \delta 190.1,166.8,159.0,153.6,153.2$, $150.1,149.8,140.5,140.0,138.5,127.3,123.6,122.9,116.0,115.7,115.3,109.4,104.2,99.6,90.5,69.3,67.9$, 
$40.3,38.8,38,6,36.4,36.2,28.8,21.1,11.5$; HRMS (TOF-ESI ${ }^{+}$) calcd. for $[\mathrm{M}+\mathrm{H}]^{+} \mathrm{C}_{31} \mathrm{H}_{37} \mathrm{~N}_{4} \mathrm{O}_{8} \mathrm{~S} \mathrm{~m} / z$ 625.2327 , found 625.2328 .

(Z)-3-Ethyl-2-(2-oxopropylidene)-2,3-dihydrobenzo[d]thiazol-5-yl (2-(2-(1-methyl-1,4-dihydroquinoline-3carboxamido)ethoxy)ethyl) carbonate (16): From quinolinium salt $15(61 \mathrm{mg}, 0.094 \mathrm{mmol})$ and BNAH (18 $\mathrm{mg}, 0.084 \mathrm{mmol})$, the expected dihydroquinoline $16(36 \mathrm{mg}, 80 \%)$ was obtained as a pale orange solid. ${ }^{1} \mathrm{H}-\mathrm{NMR}\left(300 \mathrm{MHz}, \mathrm{CDCl}_{3}\right) \delta 7.44(\mathrm{~d}, J=8.3 \mathrm{~Hz}, 1 \mathrm{H}), 7.16(\mathrm{~s}, 1 \mathrm{H}), 7.07$ (appt, $\left.J=7.6 \mathrm{~Hz}, 1 \mathrm{H}\right)$, $7.01-6.86(\mathrm{~m}, 3 \mathrm{H}), 6.80(\mathrm{appt}, J=7.3 \mathrm{~Hz}, 1 \mathrm{H}), 6.65(\mathrm{~d}, J=8.1 \mathrm{~Hz}, 1 \mathrm{H}), 5.86(\mathrm{~s}, 1 \mathrm{H}), 5.79(\mathrm{br} \mathrm{s}, 1 \mathrm{H}, \mathrm{NH})$, $4.50-4.39(\mathrm{~m}, 2 \mathrm{H}), 3.94(\mathrm{q}, J=7.2 \mathrm{~Hz}, 2 \mathrm{H}), 3.83-3.76(\mathrm{~m}, 2 \mathrm{H}), 3.73(\mathrm{~s}, 2 \mathrm{H}), 3.70-3.63(\mathrm{~m}, 2 \mathrm{H}), 3.63-3.54$ $(\mathrm{m}, 2 \mathrm{H}), 3.13(\mathrm{~s}, 3 \mathrm{H}), 2.24(\mathrm{~s}, 3 \mathrm{H}), 1.32(\mathrm{t}, J=7.1 \mathrm{~Hz}, 3 \mathrm{H}),{ }^{13} \mathrm{C}-\mathrm{NMR}\left(75 \mathrm{MHz}, \mathrm{CDCl}_{3}\right) \delta 191.6,167.7$, 160.5, 153.9, 150.2, 140.4, 140.1, 139.2, 129.6, 127.5, 125.0, 122.9, 122.5, 121.7, 115.5, 112.5, 102.9, 98.9, 90.6, $70.3,68.6,67.8,40.9,39.3,38.7,29.2,26.5,11.6$; HRMS (TOF-ESI ${ }^{+}$) calcd. for $[\mathrm{M}+\mathrm{H}]^{+} \mathrm{C}_{28} \mathrm{H}_{32} \mathrm{~N}_{3} \mathrm{O}_{6} \mathrm{~S}$ $\mathrm{m} / z$ 538.2006, found 536.2001.

\subsection{Biological Evaluation}

\subsection{1. $h \mathrm{AChE}$ and $h \mathrm{BuChE}$ Inhibition Assays}

Inhibitory capacity of compounds on $h \mathrm{AChE}$ and $h \mathrm{BuChE}$ biological activity was evaluated through the use of Ellman's spectrometric method [54]. Acetylthiocholine iodide (ATCI), butyrylcholine iodide (BTCI) and 5,5-dithiobis-(2-nitrobenzoic) acid (DTNB) were purchased from Sigma Aldrich. Lyophilized $h \mathrm{AChE}$ and $h \mathrm{BuChE}$ were purchased from Aldrich, and were diluted in phosphate buffer $(\mathrm{pH} 8)$ so as to give an enzyme solution with 0.25 units $/ \mathrm{mL}$ enzyme activity. In the procedure, $100 \mu \mathrm{L}$ of $0.3 \mathrm{mM}$ DTNB dissolved in phosphate buffer $\mathrm{pH} 7.4$ were added into the 96 well plate, followed by $50 \mu \mathrm{L}$ of the tested compound solution and $50 \mu \mathrm{L}$ of enzyme solution. After 5 min of preincubation, the reaction was then initiated by the injection of $50 \mu \mathrm{L}$ of $10 \mathrm{mM}$ ATCI or BTCI solution. The activity was determined by measuring the increase in absorbance at a wavelength of $412 \mathrm{~nm}$ every minute for 10 min using a 96 well microplate reader (Varian Carry ${ }^{\circledR} 50$ UV-Vis spectrophotometer, Darmstadt, Germany). Tested compounds were initially dissolved in analytical grade DMSO. Donepezil or Tacrine was used as reference standard. All assays were performed in duplicate, and $\mathrm{IC}_{50}$ values were determined graphically from 8 points inhibition curves using the Prism ${ }^{\circledR}$ software [51].

For the time-dependent experiments, assays were performed using a 96 well microplate reader to a final volume of $250 \mu \mathrm{L}$, a final enzyme concentration of $0.05 \mathrm{U} \cdot \mathrm{mL}^{-1}$ and an ATCI (or BTCI) and DNTB concentrations of 0.3 and $0.5 \mathrm{mM}$ respectively in phosphate buffer $(\mathrm{pH} 8)$. At the starting time $(\mathrm{t} 0)$, the inhibitor at various concentration $(150 \mu \mathrm{L})$ was added to an equivalent volume of $h \mathrm{AChE}$ (or $h \mathrm{BuChE}$ ). The mixture was then incubated at $37^{\circ} \mathrm{C}$ and, at different time points, $50 \mu \mathrm{L}$ aliquots were transferred to wells containing a solution of ATCI (or BTCI) and DTNB in phosphate buffer $(200 \mu \mathrm{L})$ and the activity was determined by measuring the changes in absorbance at $412 \mathrm{~nm}$ every minute for $10 \mathrm{~min}$. Blank experiments were also performed without inhibitor. The first order inhibition constant $k_{\text {obs }}$ was determined for all inhibitor concentrations using a nonlinear regression. Data were fitted with the equation, $A=A_{0} \exp \left(-k_{o b s} \cdot t\right)+A_{\infty}$ with $A, A_{0}, A_{\infty}$ being ratios of the inhibited enzyme activity to the control activity at time $t, 0$, and $\infty$. Double reciprocal plots of $k_{\text {obs }}$ versus the inhibitor concentration were made to determine the equilibrium constant $\mathrm{Kc}$ and the carbamoylation rate constant $\mathrm{k}_{3}$, following the described method [50].

\subsubsection{Propidium Competition Assays}

The affinity of compound $\mathbf{1 4}$ for the peripheral binding site of $e e \mathrm{AChE}$ was tested using a propidium iodide displacement assay. The assays were performed at the Centre d'Etudes et de Recherche sur le Médicament de Normandie (CERMN) in Caen, France. An increase in fluorescence on complexation of propidium iodide in $e e \mathrm{AChE}$ peripheral site was observed. Fluorescence intensity was monitored using a microplate reader. Fluorescence measurements were performed in 96 well plates, with a final volume in each well of $200 \mu \mathrm{L}$. A solution of a mixture of $e e \mathrm{AChE}$ ( $5 \mathrm{U}$ from Aldrich) 
and compound 14 (or donepezil as a control) $\left(10^{-5} \mathrm{M}\right)$ in Tris/HCl buffer $(1 \mathrm{mM}, \mathrm{pH} 8)(150 \mu \mathrm{L})$ was incubated for $6 \mathrm{~h}$ at $25^{\circ} \mathrm{C}$. A solution of propidium iodide in the same buffer $(1 \mu \mathrm{M}, 50 \mu \mathrm{L})$ was then added to the each well. After $10 \mathrm{~min}$, the fluorescence measurement was performed (excitation wavelength of $535 \mathrm{~nm}$, emission wavelength of $595 \mathrm{~nm}$ ). Each assay was performed in triplicate.

\subsubsection{DYRK1A Inhibition Assay}

Evaluation of the effects of compounds on the activity of the human recombinant DYRK1A was made using the $\mathrm{LANCE}^{\circledR}$ detection method, and was quantified by measuring the phosphorylation of Ulight-CFFKNIVTPRTPPPSQGK-amide (MBP). The assays were conducted by Eurofins Pharma Discovery in Bois l'Evêque, France. The test compounds (or staurosporine as reference or water as control) were mixed with the enzyme (11.2 ng) in a pH 7.4 Hepes/Tris buffer (40 mM Hepes/Tris, $0.8 \mathrm{mM}$ EGTA/Tris, $8 \mathrm{mM} \mathrm{MgCl}$, $1.6 \mathrm{mM}$ DTT, 0.008\% Tween 20). Next, $100 \mathrm{nM}$ of Ulight-CFFKNIVTPRTPPPSQGK-amide (MBP) and $10 \mu \mathrm{M}$ ATP were added to initiate the reaction, and the mixture was incubated for $30 \mathrm{~min}$ at $25^{\circ} \mathrm{C}$. A blank without enzyme was also performed for control basal measurements. The experiment was stopped by addition of $13 \mathrm{mM}$ EDTA, followed by the addition of the anti-phospho-MBP antibody labeled with europium chelate after $5 \mathrm{~min}$. After $1 \mathrm{~h}$ of incubation, the fluorescence was measured (excitation wavelength of $337 \mathrm{~nm}$, emission wavelength of 620 and $665 \mathrm{~nm}$ ). The enzyme activity corresponds to the ratio of signal measured at $665 \mathrm{~nm}$ to the signal measured at $620 \mathrm{~nm}$. Outputs are expressed as a percentage of inhibition of the control DYRK1A activity.

\subsubsection{PAMPA-BBB Permeability Assay}

Assays were performed at the Centre d'Etudes et de Recherche sur le Médicament de Normandie (CERMN) in Caen, France. These assays were realized according to the methodology developed by PION, by means of the Pampa-BBB Explorer ${ }^{\mathrm{TM}}$ system. This system allows the measurement of the crossing velocity of a compound from one compartment to another through an artificial membrane at $\mathrm{pH}=7.4$. The experiment was replicated 6 times in $4 \mathrm{~h}$, with quantification by UV-spectra reading. The result is given in $\mathrm{Pe}\left[\mathrm{cm} \cdot \mathrm{s}^{-1}\right]$, and an interpretation by comparison with standard compounds is proposed. The studied compounds were diluted at $20 \mathrm{mM}$ in DMSO, then diluted at $100 \mu \mathrm{L}$ in Prisma HT Buffer pH 7.4 (pION). $200 \mu \mathrm{L}$ of this solution was placed in the wells of the donor plate. $5 \mu \mathrm{L}$ of BBB-1 Lipid was placed in the filters of the acceptor plate. $200 \mu \mathrm{L}$ of Brain Sink Buffer was added in the wells of the acceptor plate. The sandwich was then assembled and incubated for $4 \mathrm{~h}$ at room temperature, without stirring. The sandwich was then separated and the UV-vis spectra of the donor and acceptor compartments were determined with the plate reader (Tecan infinite M200, Männedorf, Switzerland). Pe were calculated with the PAMPA Explorer software v.3.7 (pION Inc, Billerica, MA, USA). Standard compounds used were corticosterone and theophylline.

\subsection{Docking Simulation}

The crystal structures (PDB ID: 4EY7 and PDB 1P0I) of $h$ ACHE in complex with donepezil and of $h \mathrm{BuChE}$ in complex with butyrate were downloaded from the RCSB Web site (http:/ /www.pdb.org). The ligands were drawn in Marvin Sketch [55], hydrogen was added and their energies were minimized with Chimera 1.5.3 software with default setting [56]. Autodock Tools (ADT 1.5.6) was used to add Gasteiger charges to the ligand and to control the flexible torsions [57]. Before the docking, the protein was prepared with the DockPrep module of Chimera 1.5.3 software (National Institute of Health, Bethesda, MD, USA) using the default setting. The original crystal ligand and water molecules were removed from the protein-ligand complexes, and ADT 1.5.6 was used with the default setting to add polar hydrogen atoms and to assign Kollman charges. The docking studies of compound 14 with the $h \mathrm{AChE}$ and $h \mathrm{BuChE}$ proteins were carried out using AutodockVina [52] with the docking parameters set at default values. For $r h \mathrm{AChE}$, the box center was set to $-13.8673 /-48.5081 / 34.708$, and the box size was set to $25 / 32 / 27 \AA$. For $h \mathrm{BuChE}$, the box center was set to 139.328/112.881/37.9116; 
the box size was set to $35 / 35 / 35 \AA$ and catalytic triad and Trp82 were selected as flexible residues. Visualization was performed in PyMol 0.99rc6 [53].

Supplementary Materials: The following are available online, Copies of ${ }^{1} \mathrm{H}$ and ${ }^{13} \mathrm{C}-\mathrm{NMR}$ spectra for all synthesized compounds are provided.

Author Contributions: Conceptualization, V.G., C.P. and V.L.; Formal analysis, A.B. and R.A.; Investigation, A.B., R.A. and V.G.; Supervision, V.G., C.P. and V.L.; Validation, V.G., C.P. and V.L.; Writing-original draft, V.G.; Writing-review \& editing, V.G. and V.L.

Funding: This research was partly supported by VFP Therapies, INSA-Rouen, Rouen University, CNRS, Région Haute-Normandie and was funded by ANRT, grant number 2013/036, and by Labex SynOrg grant number ANR-11-LABX-0029.

Conflicts of Interest: The authors declare no conflict of interest.

\section{References}

1. World Health Organization. Available online: http://www.who.int (accessed on 8 February 2019).

2. Scheltens, P.; Blennow, K.; Breteler, M.M.; De Strooper, B.; Frisoni, G.B.; Salloway, S.; Van der Flier, W.M. Alzheimer's disease. Lancet 2016, 388, 505-517. [CrossRef]

3. Mehta, D.; Jackson, R.; Paul, G.; Shi, J.; Sabbagh, M. Why do trials for Alzheimer's disease drugs keep failing? A discontinued drug perspective for 2010-2015. Expert Opin. Investig. Drugs 2017, 26, 735-739. [CrossRef]

4. Anderson, R.M.; Hadjichrysanthou, C.; Evans, S.; Wong, M.M. Why do so many clinical trials of therapies for Alzheimer's disease fail? Lancet 2017, 390, 2327-2329. [CrossRef]

5. Morphy, R.; Rankovic, Z. Designed multiple ligands. An emerging drug discovery paradigm. J. Med. Chem. 2005, 48, 6523-6543. [CrossRef] [PubMed]

6. Schmitt, B.; Bernhardt, T.; Moeller, H.J.; Heuser, I.; Frölich, L. Combination therapy in Alzheimer's disease: A review of current evidence. CNS Drugs 2004, 18, 827-844. [CrossRef] [PubMed]

7. Bolognesi, M.L.; Rosini, M.; Andrisano, V.; Bartolini, M.; Minarini, A.; Tumiatti, V.; Melchiorre, C. MTDL design strategy in the context of Alzheimer's disease: From lipocrine to memoquin and beyond. Curr. Pharm. Des. 2009, 15, 601-613. [CrossRef]

8. Ferris, C.F.; Kulkarni, P.; Yee, J.R.; Nedelman, M.; de Jong, I.E.M. The Serotonin Receptor 6 Antagonist Idalopirdine and Acetylcholinesterase Inhibitor Donepezil Have Synergistic Effects on Brain Activity-A Functional MRI Study in the Awake Rat. Front. Pharmacol. 2017, 8, 279. [CrossRef] [PubMed]

9. Freret, T.; Bouet, V.; Quiedeville, A.; Nee, G.; Dallemagne, P.; Rochais, C.; Boulouard, M. Synergistic effect of acetylcholinesterase inhibition (donepezil) and 5-HT4 receptor activation (RS67333) on object recognition in mice. Behav. Brain Res. 2012, 230, 304-308. [CrossRef] [PubMed]

10. Green, K.D.; Fosso, M.Y.; Garneau-Tsodikova, S. Multifunctional Donepezil Analogues as Cholinesterase and BACE1 Inhibitors. Molecules 2018, 23, 3252. [CrossRef] [PubMed]

11. Zhao, X.J.; Gong, D.M.; Jiang, Y.R.; Guo, D.; Zhu, Y.; Deng, Y.C. Multipotent AChE and BACE-1 inhibitors for the treatment of Alzheimer's disease: Design, synthesis and bio-analysis of 7-amino-1,4dihydro2h-isoquilin-3-one derivates. Eur. J. Med. Chem. 2017, 138, 738-747. [CrossRef] [PubMed]

12. Costanzo, P.; Cariati, L.; Desiderio, D.; Sgammato, R.; Lamberti, A.; Arcone, R.; Salerno, R.; Nardi, M.; Masullo, M.; Oliverio, M. Design, synthesis, and evaluation of donepezil-like compounds as AChE and BACE-1 inhibitors. ACS Med. Chem. Lett. 2016, 7, 470-475. [CrossRef]

13. Bautista-Aguilera, Ó.M.; Hagenow, S.; Palomino-Antolin, A.; Farre-Alins, V.; Ismaili, L.; Joffrin, P.-L.; Jimeno, M.L.; Soukup, O.; Janočková, J.; Kalinowsky, L.; et al. Multitarget-Directed Ligands Combining Cholinesterase and Monoamine Oxidase Inhibition with Histamine H3R Antagonism for Neurodegenerative Diseases. Angew. Chem. Int. Ed. 2017, 56, 12765-12769. [CrossRef]

14. Sagi, Y.; Drigues, N.; Youdim, M.B. The neurochemical and behavioral effects of the novel cholinesterase-monoamine oxidase inhibitor, ladostigil, in response to L-dopa and L-tryptophan, in rats. Br. J. Pharmacol. 2005, 146, 553-560. [CrossRef] 
15. Lecoutey, C.; Hedou, D.; Freret, T.; Giannoni, P.; Gaven, F.; Since, M.; Bouet, V.; Ballandonne, C.; Corvaisier, S.; Malzert Freon, A.; et al. Design of donecopride, a dual serotonin subtype 4 receptor agonist/acetylcholinesterase inhibitor with potential interest for Alzheimer's disease treatment. Proc. Natl. Acad. Sci. USA 2014, 111, E3825-E3830. [CrossRef]

16. Li, X.; Wang, H.; Xu, Y.; Liu, W.; Gong, Q.; Wang, W.; Qiu, X.; Zhu, J.; Mao, F.; Zhang, H.; et al. Novel Vilazodone-Tacrine Hybrids as Potential Multitarget-Directed Ligands for the Treatment of Alzheimer's Disease Accompanied with Depression: Design, Synthesis, and Biological Evaluation. ACS Chem. Neurosci. 2017, 8, 2708-2721. [CrossRef]

17. Więckowska, A.; Kołaczkowski, M.; Bucki, A.; Godyń, J.; Marcinkowska, M.; Więckowski, K.; Paula Zaręba, P.; Siwek, A.; Kazek, G.; Głuch-Lutwin, M.; et al. Novel multi-target-directed ligands for Alzheimer's disease: Combining cholinesterase inhibitors and 5-HT 6 receptor antagonists. Design, synthesis and biological evaluation. Eur. J. Med. Chem. 2016, 124, 63-81. [CrossRef]

18. Jiang, X.Y.; Chen, T.-K.; Zhou, J.-T.; He, S.-Y.; Yang, H.-Y.; Chen, Y.; Qu, W.; Feng, F.; Sun, H.-P. Dual GSK-3 $\beta$ / AChE Inhibitors as a New Strategy for Multitargeting Anti-Alzheimer's Disease Drug Discovery. ACS Med. Chem. Lett. 2018, 9, 171-176. [CrossRef]

19. Oukoloff, K.; Coquelle, N.; Bartolini, M.; Naldi, M.; Le Guevel, R.; Bach, S.; Josselin, B.; Ruchaud, S.; Catto, M.; Pisani, L.; et al. Design, biological evaluation and Xray crystallography of nanomolar multifunctional ligands targeting simultaneously acetylcholinesterase and glycogen synthase kinase-3. Eur. J. Med. Chem. 2019, 106, 553-565. [CrossRef]

20. Agatonovic-Kustrin, S.; Kettle, C.; Morton, D.W. A molecular approach in drug development for Alzheimer's disease. Biomed. Pharmacother. 2018, 106, 553-565. [CrossRef]

21. Agis-Torres, A.; Sollhuber, M.; Fernandez, M.; Sanchez-Montero, J.M. Multi-Target-Directed Ligands and other Therapeutic Strategies in the Search of a Real Solution for Alzheimer's Disease. Curr. Neuropharmacol. 2014, 12, 2-36. [CrossRef]

22. Kochi, A.; Eckroat, T.J.; Green, K.D.; Mayhoub, A.S.; Lim, M.H.; Garneau-Tsodikova, S. A novel hybrid of 6-chlorotacrine and metal-amyloid- $\beta$ modulator for inhibition of acetylcholine and metal-induced amyloid- $\beta$ aggregation. Chem. Sci. 2013, 4, 4137-4145. [CrossRef]

23. Lalut, J.; Santoni, G.; Karila, D.; Lecoutey, C.; Davis, A.; Nachon, F.; Silman, I.; Sussman, J.; Weik, M.; Maurice, T.; et al. Novel multitarget-directed ligands targeting acetylcholinesterase and $\sigma 1$ receptors as lead compounds for treatment of Alzheimer's disease: Synthesis, evaluation, and structural characterization of their complexes with acetylcholinesterase. Eur. J. Med. Chem. 2019, 162, 234-248. [CrossRef]

24. Estrada Valencia, M.; Herrera-Arozamena, C.; de Andres, L.; Perez, C.; Morales-Garcia, J.A.; Perez-Castillo, A.; Ramos, E.; Romero, A.; Vina, D.; Yanez, M.; et al. Neurogenic and neuroprotective donepezil-flavonoid hybrids with sigma-1 affinity and inhibition of key enzymes in Alzheimer's disease. Eur. J. Med. Chem. 2018, 156, 534-553. [CrossRef]

25. Mao, F.; Wang, H.; Ni, W.; Zheng, X.; Wang, M.; Bao, K.; Ling, D.; Li, X.; Xu, Y.; Zhang, H.; et al. Design, Synthesis, and Biological Evaluation of Orally Available First-Generation Dual-Target Selective Inhibitors of Acetylcholinesterase (AChE) and Phosphodiesterase 5 (PDE5) for the Treatment of Alzheimer's Disease. ACS Chem. Neurosci. 2018, 9, 328-345. [CrossRef]

26. Branca, C.; Shaw, D.M.; Belfiore, R.; Gokhale, V.; Shaw, A.Y.; Foley, C.; Smith, B.; Hulme, C.; Dunckley, T.; Meechoovet, B.; et al. Dyrk1 inhibition improves Alzheimer's disease-like pathology. Aging Cell. 2017, 16, 1146-1154. [CrossRef] [PubMed]

27. Smith, B.; Medda, F.; Gokhale, V.; Dunckley, T.; Hulme, C. Recent advances in the design, synthesis, and biological evaluation of selective DYRK1A inhibitors: A new avenue for a disease modifying treatment of Alzheimer's? ACS Chem. Neurosci. 2012, 3, 857-872. [CrossRef]

28. Nguyen, T.L.; Fruit, C.; Hérault, Y.; Meijer, L.; Besson, T. Dual-specificity tyrosine phosphorylation-regulated kinase 1A (DYRK1A) inhibitors: A survey of recent patent literature. Expert Opin. Ther. Pat. 2017, 27, 1183-1199. [CrossRef]

29. Stotani, S.; Giordanetto, F.; Medda, F. DYRK1A inhibition as potential treatment for Alzheimer's disease. Future Med. Chem. 2016, 8, 681-696. [CrossRef]

30. Jarhad, D.B.; Mashelkar, K.K.; Kim, H.-R.; Noh, M.; Jeong, L.S. Dual-Specificity Tyrosine PhosphorylationRegulated Kinase 1A (DYRK1A) Inhibitors as Potential Therapeutics. J. Med. Chem. 2018, 61, 9791-9810. [CrossRef] 
31. Pathak, A.; Rohilla, A.; Gupta, T.; Akhtar, M.J.; Haider, M.R.; Sharma, K.; Haider, K.; ShaharYar, M. DYRK1A kinase inhibition with emphasis on neurodegeneration: A comprehensive evolution story-cum-perspective. Eur. J. Med. Chem. 2018, 158, 559-592. [CrossRef]

32. Ferrer, I.; Barrachina, M.; Puig, B.; Martinez de Lagran, M.; Marti, E.; Avila, J.; Dierssen, M. Constitutive Dyrk1A is abnormally expressed in Alzheimer disease, Down syndrome, Pick disease, and related transgenic models. Neurobiol. Dis. 2005, 20,392-400. [CrossRef]

33. Azorsa, D.O.; Robeson, R.H.; Frost, D.; Meec hoovet, B.; Brautigam, G.R.; Dickey, C.; Beaudry, C.; Basu, G.D.; Holz, D.R.; Hernandez, J.A.; et al. High-content siRNA screening of the kinome identifies kinases involved in Alzheimer's disease-related tau hyperphosphorylation. BMC Genom. 2010, 11, 25. [CrossRef]

34. Coutadeur, S.; Benyamine, H.; Delalonde, L.; de Oliveira, C.; Leblond, B.; Foucourt, A.; Besson, T.; Casagrande, A.S.; Taverne, T.; Girard, A.; et al. A novel DYRK1A (dual specificity tyrosine phosphorylationregulated kinase 1A) inhibitor for the treatment of Alzheimer's disease: Effect on Tau and amyloid pathologies in vitro. J. Neurochem. 2015, 133, 440-451. [CrossRef]

35. Kimura, R.; Kamino, K.; Yamamoto, M.; Nuripa, A.; Kida, T.; Kazui, H.; Hashimoto, R.; Tanaka, T.; Kudo, T.; Yamagata, H.; et al. The DYRK1A gene, encoded in chromosome 21 Down syndrome critical region, bridges between beta-amyloid production and tau phosphorylation in Alzheimer disease. Hum. Mol. Genet. 2007, 16, 15-23. [CrossRef]

36. Marsais, F.; Bohn, P.; Levacher, V.; Le Fur, N. Preparation of Dihydro Pyridines, Quinolines, and Isoquinolines as Anti-Alzheimer Agents. PCT International Applications WO 2006103120, 5 October 2006.

37. Marsais, F.; Levacher, V.; Papamicael, C.; Bohn, P.; Peauger, L.; Gembus, V.; Le Fur, N.; Dumartin-Lepine, M.-L. Oxidisable pyridine derivatives, their preparation and use as anti-alzheimer agents. PCT International Applications WO 2014114742, 31 July 2014.

38. Bohn, P.; Le Fur, N.; Hagues, G.; Costentin, J.; Torquet, N.; Papamicael, C.; Marsais, F.; Levacher, V. Rational design of central selective acetylcholinesterase inhibitors by means of a "bio-oxidisable prodrug" strategy. Org. Biomol. Chem. 2009, 7, 2612-2618. [CrossRef]

39. Peauger, L.; Azzouz, R.; Gembus, V.; Tintas, M.-L.; Sopkova-de Oliveira Santos, J.; Bohn, P.; Papamicael, C.; Levacher, V. Donepezil-based central acetylcholinesterase inhibitors by means of a "bio-oxidizable" prodrug strategy: Design, synthesis, and in vitro biological evaluation. J. Med. Chem. 2017, 60, 5909-5926. [CrossRef]

40. Azzouz, R.; Peauger, L.; Gembus, V.; Tintas, M.-L.; Sopkova-de Oliveira Santos, J.; Papamicael, C.; Levacher, V. Novel donepezil-like N-benzylpyridinium salt derivatives as AChE inhibitors and their corresponding dihydropyridine "bio-oxidizable" prodrugs: Synthesis, biological evaluation and structure-activity relationship. Eur. J. Med. Chem. 2018, 145, 165-190. [CrossRef]

41. Tintas, M.-L.; Gembus, V.; Alix, F.; Barre, A.; Coadou, G.; Truong, L.; Sebban, M.; Papamicael, C.; Oulyadi, H.; Levacher, V. Rational design of carbamate-based dual binding site and central AChE inhibitors by a "biooxidisable" prodrug approach: Synthesis, in vitro evaluation and docking studies. Eur. J. Med. Chem. 2018, 155, 171-182. [CrossRef]

42. Alix, F.; Gembus, V.; Coquet, L.; Hubert-Roux, M.; Chan, P.; Truong, L.; Sebban, M.; Coadou, G.; Oulyadi, H.; Papamicael, C.; et al. Dihydroquinoline Carbamate DQS1-02 as a Prodrug of a Potent Acetylcholinesterase Inhibitor for Alzheimer's Disease Therapy: Multigram-Scale Synthesis, Mechanism Investigations, in Vitro Safety Pharmacology, and Preliminary in Vivo Toxicology Profile. ACS Omega 2018, 3, 18387-18397. [CrossRef]

43. Ogawa, Y.; Nonaka, Y.; Goto, T.; Ohnishi, E.; Hiramatsu, T.; Kii, I.; Yoshida, M.; Ikura, T.; Onogi, H.; Shibuya, H.; et al. Development of a novel selective inhibitor of the Down syndrome-related kinase Dyrk1A. Nat. Commun. 2010, 1, 86. [CrossRef]

44. Muraki, M.; Ohkawara, B.; Hosoya, T.; Onogi, H.; Koizumi, J.; Koizumi, T.; Sumi, K.; Yomoda, J.; Murray, M.V.; Kimura, H.; et al. Manipulation of Alternative Splicing by a Newly Developed Inhibitor of Clks. J. Biol. Chem. 2004, 279, 24246-24254. [CrossRef] [PubMed]

45. Barre, A.; Tintas, M.-L.; Alix, F.; Gembus, V.; Papamicael, C.; Levacher, V. Palladium-Catalyzed Carbonylation of (Hetero)Aryl, Alkenyl and Allyl Halides by Means of N-Hydroxysuccinimidyl Formate as CO Surrogate. J. Org. Chem. 2015, 80, 6537-6544. [CrossRef] [PubMed] 
46. Greig, N.H.; Utsuki, T.; Ingram, D.K.; Wang, Y.; Pepeu, G.; Scali, C.; Yu, Q.S.; Mamczarz, J.; Holloway, H.W.; Giordano, T.; et al. Selective butyrylcholinesterase inhibition elevates brain acetylcholine, augments learning and lowers Alzheimer beta-amyloid peptide in rodent. Proc. Natl. Acad. Sci. USA 2005, 102, 17213-17218. [CrossRef]

47. Nordberg, A.; Ballard, C.; Bullock, R.; Darreh-Shori, T.; Somogyi, M. A Review of Butyrylcholinesterase as a Therapeutic Target in the Treatment of Alzheimer's Disease. Prim. Care Companion CNS Disord. 2013, 15. [CrossRef]

48. Johnson, G.; Moore, S.W. The peripheral anionic site of acetylcholinesterase: Structure, functions and potential role in rational drug design. Curr. Pharm. Des. 2006, 12, 217-225. [CrossRef] [PubMed]

49. Hosie, L.; Sutton, L.D.; Quinn, D.M. p-Nitrophenyl and Cholesteryl-N-Alkyl Carbamates as Inhibitors of Cholesterol Esterase. J. Biol. Chem. 1987, 262, 260-264, CODEN: JBCHA3. [PubMed]

50. Feaster, S.R.; Lee, K.; Baker, N.; Hui, D.Y.; Quinn, D.M. Molecular Recognition by Cholesterol Esterase of Active Site Ligands: Structure-Reactivity Effects for Inhibition by Aryl Carbamates and Subsequent Carbamyl enzyme Turnover. Biochemistry 1996, 35, 16723-16734. [CrossRef] [PubMed]

51. GraphPad Prism Version 8.0.1; GraphPad Software: San Diego, CA, USA, 2018.

52. Trott, O.; Olson, A.J. AutoDock Vina: Improving the speed and accuracy of docking with a new scoring function, efficient optimization and multithreading. J. Comput. Chem. 2010, 31, 455-461. [CrossRef]

53. PyMol 0.99rc6; DeLano Scientific: San Carlo, CA, USA, 2006.

54. Ellman, G.L.; Courtney, K.D.; Andres, V., Jr.; Featherstone, R.M. A new and rapid colorimetric determination of acetylcholinesterase activity. Biochem. Pharmacol. 1961, 7, 88-95. [CrossRef]

55. Marvin Sketch 17.29.0. ChemAxon Ltd. 1998-2017. Available online: http://www.chemaxon.com (accessed on 31 March 2019).

56. Pettersen, E.F.; Goddard, T.D.; Huang, C.C.; Couch, G.S.; Greenblatt, D.M.; Meng, E.C.; Ferrin, T.E. UCSF Chimera-A visualization system for exploratory research and analysis. J. Comput. Chem. 2004, 25, 1605-1612. [CrossRef]

57. Sanner, M.F. Python: A Programming Language for Software Integration and Development. J. Mol. Graph. Mod. 1999, 17, 57-61.

Sample Availability: Not available.

(C) 2019 by the authors. Licensee MDPI, Basel, Switzerland. This article is an open access article distributed under the terms and conditions of the Creative Commons Attribution (CC BY) license (http://creativecommons.org/licenses/by/4.0/). 